\title{
Cara Apoteker Menjalankan Bisnis Pedagang Besar Farmasi (PBF)
}

\author{
Resha Gilar Tamara \\ Program Studi Profesi Apoteker, Fakultas Farmasi, Universitas Padjadjaran, Sumedang, 45363 \\ email: resha.gilar.tamara@gmail.com
}

\section{Abstrak :}

Dalam upaya mewujudkan masyarakat yang sehat dibutuhkan penyediaan obat berkualitas. Kualitas obat tersebut harus dijamin dari mulai produksi hingga mencapai masyarakat atau konsumen, salah satu titik kritis adalah kegiatan penyaluran obat. Industri farmasi menyalurkan produknya menggunakan jasa distributor atau disebut juga Pedagang Besar Farmasi (PBF). PBF memiliki wewenang untuk menyalurkan obat antar PBF atau PBF cabang lainnya dan fasilitas kefarmasian (apotek, instalasi farmasi rumah sakit, puskesmas, klinik, dan toko obat). PBF harus menerapkan pola bisnis demi mendukung tercapainya target perusahaan. Pola bisnis tersebut meliputi pengadaan dan pemesanan barang, penerimaan barang, penyimpanan, penerimaan pesanan, pengiriman pesanan, dan penagihan pembayaran.

Keyword : apoteker, pedagang besar farmasi, konsumen

\section{Outline}

- Pendahuluan

- Penerimaan Barang

- Penyimpanan

- Penerimaan Pesanan

- Penagihan Pembayaran

- Kesimpulan

\section{Pendahuluan}

Bisnis menurut terminologis adalah suatu kegiatan atau usaha. Bisnis dapat diartikan juga sebagai aktivitas terpadu dalam pertukaran barang, jasa, atau uang yang dilakukan oleh dua pihak atau lebih dengan tujuan memperoleh keuntungan (Griffin dan Ebert, 2008).

\section{Pola Bisnis Pedagang Besar Farmasi (PBF)}

PBF harus menerapkan pola bisnis demi mendukung tercapainya target perusahaan. Pola bisnis tersebut meliputi pengadaan dan pemesanan barang, penerimaan barang, penyimpanan, penerimaan pesanan, pengiriman pesanan, dan penagihan pembayaran.

\section{Pengadaan dan Pemesanan Barang}

Pengadaan dan pemesanan barang dilakukan berdasarkan history penjualan, pareto, permintaan pasar, dan program pihak marketing. Dalam sistem pengadaan, dilakukan penentuan level persediaan produk berdasarkan penentuan nilai Level Stock, Buffer Stock, Lead Time, dan ReOrder Point (ROP). 
Pengadaan dilakukan oleh Apoteker Penanggung Jawab (APJ) PBF dengan membuat defekta, berkoordinasi dengan supervisior penjualan dan bagian marketing dalam membuat daftar kebutuhan barang. Pada proses pengadaan dibagi menjadi 3 kelompok, yaitu pengadaan produk reguler, produk e-catalogue, dan produk berupa Narkotika/Psikotropika/Prekursor (NPP).

Pengadaan yang dilakukan harus mengikuti kaidah $\mathrm{CDOB}$, yaitu setiap pengadaan dikendalikan dengan prosedur tertulis dan rantai pasok diidentifikasi serta didokumentasikan.

\section{Penerimaan Barang}

Untuk memastikan bahwa obat yang diterima dalam keadaan baik, sah, sesuai dengan yang dipesan, maka dilakukan pemeriksaan pada saat obat diterima oleh bagian Transito dengan menggunakan checklist pada faktur pembelian yang diterima dan Rincian Surat Kirim Barang. Hal tersebut sesuai dengan petunjuk pelaksanaan CDOB yaitu dalam penerimaan harus terdapat checklist yang berisi nama pemasok, nama barang, nomor bets, tanggal kadaluwarsa, jumlah fisik, dan keutuhan fisik produk.

\section{Penyimpanan}

Sistem penyimpanan obat biasanya menggunakan sistem First Expired First Out (FEFO); obat-obat yang tanggal kadaluwarsanya lebih dekat dijual atau didistribusikan terlebih dahulu. Untuk produk kemasan dus kemasan utuh obat disimpan diatas rak dengan sistem penempatan berdasarkan golongan obat, jenis produk, fast-moving/slow-moving, dan berdasarkan analisis efisiensi kerja. Penempatan sediaan cair yang disertai kemasan yang mudah pecah disimpan pada bagian bawah rak untuk mengurangi risiko terjatuh pada saat pengambilan barang.

Barang yang ada di gudang PBF harus disimpan pada kondisi yang sesuai seperti yang telah ditetapkan oleh pabriknya; misalnya vaksin disimpan pada suhu dingin di dalam Chiller yang dilengkapi dengan thermometer untuk monitoring suhu dan dokumen pencatatan suhu.

\section{Penerimaan Pesanan}

Proses pelayanan penjualan sediaan farmasi di PBF dilakukan dengan mengirim secara tertulis melalui Surat Pesanan (SP) yang ditandatangani oleh Apoteker penanggung jawab. Penerimaan SP dilayani dengan beberapa cara yaitu pemesanan melalui salesman di sarana kefarmasian pelanggan ataupun pesanan langsung melalui telepon/faximile. Apabila pemesanan dilakukan melalui telepon maka Surat Pesanan asli harus diserahkan pada saat obat diterima. Untuk pembelian barang dapat dilakukan dengan pembayaran tunai dan kredit. Untuk pemesanan narkotika, psikotropika dan prekursor (NPP) wajib menggunakan SP khusus sesuai peruntukkannya, diterima dan ditanda tangani langsung oleh Apoteker Penanggung Jawab Apotek (APA) dan di bubuhi stempel asli serta harus sesuai keabsahannya dengan specimen disertai dengan jumlah pemesanan yang wajar. 


\section{Pengiriman Pesanan}

Pengiriman obat dan/atau bahan obat di PBF biasanya menggunakan jasa pihak ketiga yang telah terikat kontrak dan mampu menerapkan prinsip CDOB dalam pengiriman obat dan/atau bahan obat. Pada saat akan dilakukan pengiriman, dilakukan cross check terlebih dahulu pada produk yang telah disiapkan bagian logistik. Hal yang dicek meliputi nama outlet pemesan, nama barang, kekuatan sediaan, nomor bets, tanggal kadaluwarsa, jumlah fisik, dan jumlah pesanan.

\section{Penagihan Pembayaran}

PBF biasanya melakukan penjualan secara kredit yang dilakukan oleh salesman melalui instruksi manajemen penjualan. Outlet membuat pesanan yang diserahkan ke salesman kemudian dibuatkan faktur penjualan oleh fakturis lalu barang dan faktur penjualan dikirimkan menuju outlet. APJ outlet menandatangani dan memberi stempel pada faktur penjualan, kemudian faktur penjualan asli diarsipkan oleh bagian piutang PBF untuk proses penagihan pada saat jatuh tempo.

Saat faktur penjualan telah jatuh tempo, bagian piutang PBF menyerahkan faktur penjualan tersebut kepada kolektor atau salesman untuk dilakukan penagihan kepada outlet terkait. Bila outlet masih belum membayar utangnya, maka outlet tersebut tidak dapat memesan barang karena sistem di PBF akan otomatis menolak pemesanan outlet tersebut.

\section{Kesimpulan}

Penyediaan obat berkualitas sangat dibutuhukan oleh masyarakat. Selain menerapkan pola bisnis, PBF harus senantiasa menjaga obat agar tetap berkualitas sampai ke tangan konsumen.

\section{Daftar pustaka :}

Badan Pengawas Obat dan Makanan RI. 2012. Peraturan Kepala Badan Pengawas Obat dan Makanan Republik Indonesia Nomor: HK.03.1.34.11.12.7542 Tahun 2012 Tentang Pedoman Teknis Cara Distribusi Obat yang Baik. Jakarta: BPOM.

Griifin, R. W dan Ebert, R. J. 2008. Bisnis, edisi 8. Jakarta : Erlangga.

Kementerian Kesehatan. 2014. Peraturan Menteri Kesehatan No. 34 Tahun 2014 tentang Perubahan Atas Peraturan Menteri Kesehatan Nomor 1148/Menkes/Per/VI/2011 tentang Pedagang Besar Farmasi. Jakarta: Kementerian Kesehatan Republik Indonesia. 